\title{
Hearing Loss A Triggering Factor to Depression: A Systematic Review
}

\author{
Manisha Choudhury* \\ Assistant Professor, Department of Audiology and Speech Language Pathology, Amity University Gurugram, India \\ *Corresponding author: Manisha Choudhury, Assistant Professor, Department of Audiology and Speech Language Pathology, Amity \\ University Gurugram, India
}

\begin{abstract}
Introduction: Hearing loss is a hidden disability that affects the hearing ability of an individual and makes it difficult to recognize or discriminate the various auditory signals. People who usually suffer from hearing loss tend to exhibit heterogeneous characteristics comprising of diverse and complex psychosocial behaviours which includes resentment, hostility, rejection and subtle denial resulting to a significant deterioration on socio-emotional development which could ultimately lead to serious mental illness like depression.
\end{abstract}

Objective: Present review study was conducted to assess the comprehensiveness and trend of various other studies related to impact of hearing loss in individuals leading to depression by assembling diversified online data bases from various sources.

Methods: To conduct this systematic review, a thorough search was framed across multiple databases which was based upon exploration of five facets ("hard of hearing", "stress and symptoms of depression", "depression", "hearing impairment" and "deaf" and). Almost five electronic databases, key texts and references in the articles were identified and critically analysis was done for those articles that had information regarding "hearing loss" and "depression".

Results: Data accumulated from the databases indicated that hearing loss is a leading factor to depression which has a strong association with the onset and degrees of hearing loss, that acts as a major correlate of depressive symptoms among the geriatric population.

Conclusion: Studies show that there is a considerable propensity for depression among individuals with hearing loss which can also induce suicidal thoughts. Therefore, there should always be an interdisciplinary team approach to establish a well- defined intervention plan for individuals who suffer from hearing loss resulting in mental illness.

Keywords: Hearing loss; Depression; Mental illness

\section{Introduction}

Mental health is a condition that has an intensive impact on the general wellbeing of an individual as a whole. It actually acts as reflection which provides a sense of satisfaction to an individual or to the society. In other words, it predetermines how an individual respond to societal issues, inter and intrapersonal relationship in social context. However, when a concern regarding mental health status arises, it becomes a serious threat for the individual or to the entire society. The associated result of the mental health issue can be disastrous most especially at adolescence and adulthood [1]. Based on Sommers' survey [1], the effect of hearing loss on mental health among individuals with hearing loss becomes evident when disability starts effecting the communicative skills which in turn becomes a serious concern. Hearing loss basically includes those who group of individuals who are Deaf and/or Hard of hearing. In other words, the inability to perceive or comprehend any kind of auditory/verbal stimulus as compared to individuals with normal hearing ability has an extensive impact on psychosocial development of individuals with hearing loss. The most crucial effect in the life of an individual with hearing loss is incompetent to follow verbal instructions, and this limits the potentiality to develop speech and language skills which is the essential for communication thus having a cascading effect every aspect of human life including emotional and social development, family interconnectedness, social competence and over all perceived 
quality of life [2]. Current research studies indicate that persons with hearing impairment tend to exhibit more behavioural and social problems as compared to normal peers $[3,4]$, they frequently experience a greater deal of psychosocial challenges with reduced satisfaction, lack of interests in physical and other recreational activities [4]. Individuals with varying types of hearing loss also tend to show increased rate of being withdrawn or isolated $[5,6]$. Moreover, in such population access to incidental learning is often confined because of difficulties in communication and the level hearing loss per se. These individuals may often reflect difficulties in cognitive activities like abstract thinking and tasks related to problem-solving [7], ability to form social relationships, very low self-esteem [8] and resulting in high psychological distress causing stress or depression [9]. As mentioned earlier, individuals with hearing loss also have risks related to health and environmental hazards, more prone to maladjustment in social environment, sleep disturbances/insomnia and feasibility of inducing depressive symptoms when compared to normal hearing population [10].

According to World Health Organization [11], depression is regarded as a serious mental condition which affects an individual with notable depressed mood, displeasure, feelings of guilt and reduced self-worth, decreased energy, disturbed sleep, loss of appetite, and poor concentration. Additionally, there is a close relationship between symptoms of anxiety with depression which could result in substantial comorbid conditions that may negatively influence on everyday responsibilities. Studies have also revealed that slowed responses, tearfulness, loss of appetite, as well as sleep problems, loss of interest or societal withdrawal from family and friends are indicative of depressed individual with hearing loss [12]. Depressive disorders at adult stage is considered as a precursor from the most susceptible age range especially during adolescence $[13,14]$. Kim-Cohen et al. [15] conducted a study among 1,037 individuals who had history of depression and results indicated that only $25 \%$ of participants had suffered from depression at adulthood while $75 \%$ of adults who met the criteria for major depression, had an significant history of depressive disorder in childhood or adolescence. A similar kind of study was conducted by Moffitt et al. [16], which revealed that the prevalence of major depressive disorders ranges from 10\%-17\% in early adulthood period with more depressive symptoms observed in women as compared to men [17]. In other words, symptoms of depressive disorders starts to evolve between 4-5\% during early teenager age period especially more common in girls due to the pubertal physical reformation which is much self-evident than in boys [18]. Various research studies also state that incidence of psychopathology in children and adolescents tends to be higher depending on the various degrees of hearing loss [19]. But still, there is still controversial discussions as there in lack of studies that can mention the exact age period of depression as other factors associated with depressive symptoms among adolescence seems vary from individual to individual [20,21]. According to World health Organization [22] depression is one of the leading causes of disability with a $50 \%$ higher rate among women than men. It also co-exists or emerge due to other disabling conditions for persons with hearing loss. Research studies also indicate that individuals with hearing loss most especially African Countries Individuals with hearing loss suffer more from depression and psychosocial issues [23], poor academic achievement [24,25], delay in speech and language acquisition [26]. Based on the fact that individuals with hearing loss are more susceptible to having mental health problems due to their inability to communicate with the hearing world. This review study aims to determine the extent of studies which are being conducted on depression and depressive symptoms among persons who are suffering from hearing loss which are based on the open access. Moreover, this study will provide an insight on the regarding the impact of hearing loss on mental health among persons with hearing loss across various countries.

\section{Method}

A comprehensive review of articles on 'depression' and 'hearing loss' or hard of hearing and/or deafness reflected in respective research title were identified and considered for the selected study. However, such article must be completed and published from 2010 up to May 2019. The studies incorporated in the present review were identified by keyword searches from various database sources like PubMed data, Science Direct, and the widely accepted web using Google Scholar. Only those articles which were written in English language was identified and analysed for the current study [27-39]. The search was also extensively done by include other expandable keywords like 'depressive symptoms' and 'Mental Health and Deafness', 'Effect of depressive symptoms and Onset of hearing loss'. A The relevant articles searched and considered are presented below (Table 1).

\section{Table 1.}

\begin{tabular}{|c|c|c|c|c|c|}
\hline Author(s) & $\begin{array}{c}\text { Year/ Place of } \\
\text { Publication }\end{array}$ & Paper title & Type of study & Participants & Results \\
\hline $\begin{array}{c}\text { Nkyekyer et } \\
\text { al. [27] }\end{array}$ & 2019, Australia & $\begin{array}{c}\text { The cognitive and } \\
\text { psychosocial effects of } \\
\text { auditory training and } \\
\text { hearing aids in adults with } \\
\text { hearing loss }\end{array}$ & Pilot study & $\begin{array}{c}\text { A total of 40 participants } \\
\text { aged 50-90 years were } \\
\text { given questionnaires } \\
\text { related to cognition and } \\
\text { health }\end{array}$ & $\begin{array}{c}\text { Hearing loss adversely affects } \\
\text { cognition and mental health which } \\
\text { can be improved by providing better } \\
\text { hearing amplification device. }\end{array}$ \\
\hline $\begin{array}{c}\text { Simning et } \\
\text { al.[28] }\end{array}$ & 2018 & $\begin{array}{c}\text { Depressive and Anxiety } \\
\text { Symptoms in Older Adults } \\
\text { with Auditory, Vision, and } \\
\text { Dual Sensory Impairment }\end{array}$ & Cross-sectional & $\begin{array}{c}\text { A total 7,507 older adults } \\
\text { from the National Health } \\
\text { and Aging Trends were } \\
\text { selected for the study }\end{array}$ & $\begin{array}{c}\text { Auditory, vision, and dual } \\
\text { impairment is strongly associated } \\
\text { wincreased risk for depressive } \\
\text { and anxiety symptoms. }\end{array}$ \\
\hline
\end{tabular}




\begin{tabular}{|c|c|c|c|c|c|}
\hline $\begin{array}{c}\text { Shin \& } \\
\text { Hwang [29] }\end{array}$ & 2017, Korea & $\begin{array}{l}\text { Mental Health of the People } \\
\text { with Hearing Impairment in } \\
\text { Korea: A Population-Based } \\
\text { Cross-Sectional Study }\end{array}$ & Survey & $\begin{array}{c}18,563 \text { individuals }(6,395 \\
\text { with hearing impairment } \\
\text { and } 12,168 \text { without hearing } \\
\text { impairment), aged } \geq 20 \\
\text { years }\end{array}$ & $\begin{array}{l}\text { The female participants with hearing } \\
\text { impairment indicated to have a } \\
\text { higher rate of stress with suicidal } \\
\text { attempt was higher in elderly } \\
\text { females. }\end{array}$ \\
\hline $\begin{array}{l}\text { Zamora-Vega } \\
\text { et al. [30] }\end{array}$ & 2016 & $\begin{array}{c}\text { Association between } \\
\text { depression and hearing } \\
\text { loss in patients with type } 2 \\
\text { diabetes }\end{array}$ & $\begin{array}{l}\text { Cross-sectional } \\
\text { analytical study }\end{array}$ & $\begin{array}{c}150 \text { patients with type } 2 \\
\text { diabetes ( } 76 \% \text { women and } \\
34 \% \text { men })\end{array}$ & $\begin{array}{l}\text { Patients with diabetes having } \\
\text { hearing loss were at higher risk of } \\
\text { depression. }\end{array}$ \\
\hline $\begin{array}{l}\text { Castiglione et } \\
\text { al. [31] }\end{array}$ & 2016 & $\begin{array}{l}\text { Aging, cognitive decline } \\
\text { and hearing loss: Effects } \\
\text { of auditory rehabilitation } \\
\text { and training with hearing } \\
\text { aids and cochlear implants } \\
\text { on cognitive function and } \\
\text { depression among older } \\
\text { adults. }\end{array}$ & $\begin{array}{l}\text { Quasi- } \\
\text { experimental } \\
\text { study }\end{array}$ & $\begin{array}{c}125 \text { total participants } \\
\text { were selected (105 with } \\
\text { hearing impairment and } 20 \\
\text { with } \neg \text { out hearing loss) }\end{array}$ & $\begin{array}{l}\text { Significant improvement was } \\
\text { observed after auditory training } \\
\text { on cognitive tasks, level of } \\
\text { depression and cognitive status } \\
\text { scores also showed positive results. } \\
\text { Amplification devices such as } \\
\text { Cochlear implants or hearing aids } \\
\text { showed better effectiveness among } \\
\text { older adults (median age of } 74 \text { years) } \\
\text { with different degrees of hearing loss } \\
\text { in terms depression and cognitive } \\
\text { performance }\end{array}$ \\
\hline $\begin{array}{l}\text { Dawas et al. } \\
{[32]}\end{array}$ & 2015 & $\begin{array}{l}\text { Hearing loss and cognition: } \\
\text { The role of hearing aids, } \\
\text { social isolation and } \\
\text { depression }\end{array}$ & $\begin{array}{l}\text { Correlational } \\
\text { study }\end{array}$ & $\begin{array}{c}164,770 \text { participants from } \\
\text { (40 to } 69 \text { years) }\end{array}$ & $\begin{array}{l}\text { The study recorded better cognition, } \\
\text { independently of social isolation and } \\
\text { depression among hearing aid users. }\end{array}$ \\
\hline \multirow{2}{*}{ Li, et al. [33] } & \multirow{2}{*}{ 2014, USA } & $\begin{array}{l}\text { Hearing impairment } \\
\text { associated with depression } \\
\text { in US adults, }\end{array}$ & \multirow{2}{*}{$\begin{array}{l}\text { Descriptive } \\
\text { survey study }\end{array}$} & \multirow{2}{*}{$\begin{array}{l}18318 \text { subjects aged } 18 \\
\text { years or older. }\end{array}$} & \multirow{2}{*}{$\begin{array}{l}\text { Hearing impairment and depression } \\
\text { among all participants was } \\
\text { significantly associated, increased } \\
\text { risk was seen among women than } \\
\text { male subjects. }\end{array}$} \\
\hline & & $\begin{array}{l}\text { National Health and } \\
\text { Nutrition Examination } \\
\text { Survey 2005-2010 }\end{array}$ & & & \\
\hline $\begin{array}{l}\text { Rostami, et } \\
\text { al. [34] }\end{array}$ & 2014, Iran & $\begin{array}{l}\text { Depression and Deaf } \\
\text { adolescents: A review }\end{array}$ & Review study & & $\begin{array}{l}\text { Depressive symptoms tend to be } \\
\text { more prevalent in the deaf than in } \\
\text { hearing students }\end{array}$ \\
\hline $\begin{array}{c}\text { Prakash et al. } \\
\text { [35] }\end{array}$ & 2013, India & $\begin{array}{l}\text { Measuring levels of stress } \\
\text { and depression in Mothers } \\
\text { of children using hearing } \\
\text { aids and cochlear implants: } \\
\text { A comparative study }\end{array}$ & $\begin{array}{l}\text { Comparative } \\
\text { nature of study }\end{array}$ & $\begin{array}{l}50 \text { Mothers of children with } \\
\text { bilateral severe to profound } \\
\text { sensorineural hearing loss }\end{array}$ & $\begin{array}{l}\text { The findings of the study indicated } \\
\text { that stress and depression levels } \\
\text { are higher among mothers of } \\
\text { children with hearing loss who use } \\
\text { amplification devices in comparison } \\
\text { to the mothers of children using } \\
\text { cochlear implants users. }\end{array}$ \\
\hline $\begin{array}{l}\text { Garnefski et } \\
\text { al. [36] }\end{array}$ & 2012 & $\begin{array}{l}\text { Cognitive coping and } \\
\text { goal adjustment are } \\
\text { associated with symptoms } \\
\text { of depression and anxiety } \\
\text { in people with acquired } \\
\text { hearing loss }\end{array}$ & $\begin{array}{l}\text { Cross-section } \\
\text { study }\end{array}$ & $\begin{array}{l}119 \text { individuals with } \\
\text { moderate to profound } \\
\text { degree of hearing loss }\end{array}$ & $\begin{array}{l}\text { The study revealed serious concern } \\
\text { of implementing coping strategies } \\
\text { which were related to the symptoms } \\
\text { of depression and/or anxiety among } \\
\text { the participants in the study. }\end{array}$ \\
\hline $\begin{array}{l}\text { Millán- } \\
\text { Calenti et al. } \\
\text { [37] }\end{array}$ & 2011 & $\begin{array}{l}\text { Relationship between } \\
\text { sensory hearing loss and } \\
\text { depression in elderly } \\
\text { people: A literature review }\end{array}$ & A review study & & $\begin{array}{l}\text { Quality of life among elderly persons } \\
\text { with hearing loss was significantly } \\
\text { affected by communication } \\
\text { difficulties which restricted the } \\
\text { social participation and effective } \\
\text { communication skills. }\end{array}$ \\
\hline $\begin{array}{l}\text { Theunissen } \\
\text { et al. [38] }\end{array}$ & 2011 & $\begin{array}{l}\text { Depression in hearing- } \\
\text { impaired children }\end{array}$ & $\begin{array}{l}\text { Descriptive } \\
\text { survey research }\end{array}$ & $\begin{array}{l}27 \text { children with cochlear } \\
\text { implants, } 56 \text { children with } \\
\text { conventional hearing aids, } \\
\text { and } 117 \text { normally hearing } \\
\text { children. }\end{array}$ & $\begin{array}{l}\text { Depressive symptoms were reported } \\
\text { more among children with hearing } \\
\text { loss compared to normally hearing } \\
\text { peers. }\end{array}$ \\
\hline Lee et al. [39] & 2010, China & $\begin{array}{l}\text { Hearing impairment and } \\
\text { depressive symptoms in an } \\
\text { older Chinese population }\end{array}$ & $\begin{array}{l}\text { Cross-sectional } \\
\text { study }\end{array}$ & $\begin{array}{l}914 \text { Community-dwellers } \\
\text { who were aged } 60 \text { years }\end{array}$ & $\begin{array}{l}\text { An association was found between } \\
\text { depression and hearing loss in older } \\
\text { Chinese. }\end{array}$ \\
\hline
\end{tabular}

\section{Discussion and Conclusion}

Hearing loss is a hidden disability that has an immense negative impact in the quality of life among individuals of any age group from neonates to older adults. Hearing loss irrespective of any degree or configuration plays a role in compromising acquiring communication skills, education, social functioning of the individual. It is the greatest handicap which revolves around the development of speech and language skills; however, because hearing loss is 
a masked disability, it often neglected, when associated health issues are also present. It may have hazardous effect for overall development of an individual [40]. Oyiborhoro concluded in the study that the difficulties faced by children with hearing loss can extend beyond the academic area which can interfere in the entire social and emotional development resulting in various emotional which can persist even till adulthood [41]. Studies have also indicated that persons with hearing loss found often tend to face situations related to physical abuse, illness or additional disability, as well as feeling withdrawal or isolation from family [42-44]. This review was conducted to highlight the trend of research and trace the effect of hearing loss on depression on individuals with hearing loss. The review also throws light on the associated factors which predispose the depressive symptoms among the Deaf and/or hard of hearing that may lead to suicidal attempts among persons with hearing loss. Hence, when planning an intervention programme for a person with hearing loss should consist of a team which must include audiologist along with psychologist, psychiatrist, sign language interpreters and other professionals. In future, various other similar studies can be conducted by other professional dealing with mental health research and should beam the light on depressive symptoms among persons with hearing loss. Such future studies should also consider the various diversities among persons with hearing loss that will provide the actual evidences and also provide an insight on the prevalence of depression and its symptoms among persons with hearing loss across the world. Apart from these evidences, studies should also focus more on children and adolescents with post-lingual hearing loss while audiologist and the entire team consisting of psychologist should not presume or infer any depressive symptoms among persons with hearing loss without proper intervention.

\section{Refernces}

1. Sommers J (2014) The mental health status of deaf and hard of hearing children in the mainstream education system. Undergraduate Honors Theses.

2. Heward WL (2009) Exceptional children: An introduction to special education. Prentices Hall, New Jersey, USA.

3. Oyewumi AM (2013) Teachers perception of emotional and behavioural disorder among primary school children with hearing impairment. Nigeria J Clin Counsel Psychol 19: 87-99.

4. Oyewumi AM, Akangbe T, Adigun OT (2013) Personality factors as correlates of perceived quality of life among adolescents with hearing impairment in selected secondary schools in Lagos State, Nigeria. J Educ Pract 4: 162-168.

5. Hogan A, Shipley M, Strazdins L, Purcell A, Baker E (2011) Communication and behavioural disorders among children with hearing loss increases risk of mental health disorders. Aust N Z J Public Health 35: 377-383.

6. Fellinger J, Holzinger D, Sattel H, Laucht M (2008) Mental health and quality of life in deaf pupils. Eur Child Adolesc Psychiatry 17: 414-423.

7. Marschark M (2005) Developing deaf children or deaf children developing? In: D Power, G. Leigh (Eds.), educating deaf students: Global perspectives. Gallaudet University Press, Washington, DC, USA.

8. Scheetz NA (2004) Psychosocial aspect of deafness. Pearson Education, Massachusetts, USA.

9. Brown PM, Cornes A (2015) Mental health of deaf and hard-of-hearing adolescents: What the students say? J Deaf Stud Deaf Educ 20: 75-81.
10. Remine MD, Brown PM (2010) Comparison of the prevalence of mental health problems in deaf and hearing children and adolescents in Australia. Aust N Z J Psychiatry 44: 351-357.

11. World Health Organization (2012) World suicide prevention day.

12. Rostami M, Bahmani B, Bakhtyari V, Movallali G (2014) Depression and Deaf Adolescents: A review. Ira Reh J 12: 43-53.

13. Keller MB, Lavori PW, Beardslee WR, Wunder J, Ryan N (1991) Depression in children and adolescents: new data on 'under treatment' and a literature review on the efficacy of available treatments. J Affect Disord 21: 163-171.

14. Bulhões C, Ramos E, Lindert J, Dias S, Barros H (2013) Depressive symptoms and its associated factors in 13 year old urban adolescents. Int J Environ Res Public Health 10: 5026-5038.

15. Kim-Cohen J, Caspi A, Moffitt TE, Harrington H, Milne BJ, et al. (2003) Prior juvenile diagnoses in adults with mental disorder: Developmental follow-back of a prospective-longitudinal cohort. Arch Gen Psychiatry 60: 709-717.

16. Moffitt TE, Caspi A, Taylor A, Kokaua J, Milne BJ, etal. (2010) How common are common mental disorders? Evidence that lifetime prevalence rates are doubled by prospective versus retrospective ascertainment. Psychol Med 40: 899-909.

17. Lewinsohn PM, Rohde P, Seeley JR, Klein DN, Gotlib IH (2000) Natural course of adolescent major depressive disorder in a community sample: Predictors of recurrence in young adults. Am J Psychiatry 157: 15841591.

18. Thapar A, Collishaw S, Pine DS, Thapar AK (2012) Depression in adolescence. Lancet 379: 1056-1067.

19. Van Gent T, Goedhart AW, Treffers PDA (2012) Characteristics of children and adolescents in the Dutch national in- and out-patient mental health service for deaf and hard of hearing youth over a period of 15 years. Res Dev Disabil 33: 1333-1342.

20. Mejstad L, Heiling K, Svedin CG (2009) Mental health and self-image among deaf and hard of hearing children. Am Ann Deaf 153: 504-515.

21. Purvis D, Robinson E, Merry S, Watson P (2006) Acne, anxiety, depression and suicide in teenagers: A cross-sectional survey of New Zealand secondary school students. J Paediatr Child Health 42: 793-796.

22. Frojd SA, Nissinen ES, Pelkonen MU, Marttunen MJ, Koivisto AM (2008) Depression and school performance in middle adolescent boys and girls. J Adolesc 31: 485-498.

23. World Health Organization (2008) The Global Burden of Disease: 2004 Update. World Health Organization, Geneva, Switzerland.

24. Oyewumi AM, Sotade FR (2010) Stress Coping Mechanisms among Parents of Children with Hearing Loss in Ogun State, Nigeria. Int J Appl Psychol Hum Performance 6: 1405-1418.

25. Morere D (2013) Measures of reading achievement. In: Morere D, Allen T (Eds.), Assessing literacy of deaf individuals. Springer, New York, USA.

26. Knoors H, Marschark M (2012) Language planning for the $21^{\text {st }}$ century: Revisiting bilingual language policy for deaf children. J Deaf Stud Deaf Educ 17: 291-305.

27. Nkyekyer, J, Meyer, D, Pipingas, A, Reed, NS (2019) The cognitive and psychosocial effects of auditory training and hearing aids in adults with hearing loss. Clinical interventions in aging 14: 123.

28. Simning A, Fox ML, Barnett SL, Sorensen S, Conwell Y (2018) Depressive and anxiety symptoms in older adults with auditory, vision, and dual sensory impairment. Journal of aging and health.

29. Shin HY, Hwang HJ (2017) Mental health of the people with hearing impairment in Korea: A population-based cross-sectional study. Korean journal of family medicine 38(2): 57-63.

30.Zamora-Vega 0, Gómez-Díaz RA, Delgado-Solís M, Vázquez-Estupiñán F, Vargas-Aguayo AM, et al. (2017). Association between depression 
and hearing loss in patients with type 2 diabetes. Revista Médica del Instituto Mexicano del Seguro Social 54(S2):140-147.

31. Castiglione A, Benatti A, Velardita C, Favaro D, Padoan E, et al. (2016) Aging, cognitive decline and hearing loss: effects of auditory rehabilitation and training with hearing aids and cochlear implants on cognitive function and depression among older adults. Audiology and Neurotology 21(Suppl 1): 21-28.

32. Dawes P, Emsley R, Cruickshanks KJ, Moore DR, Fortnum H, et al. (2015) Hearing loss and cognition: the role of hearing AIDS, social isolation and depression. PloS one 10(3): e0119616.

33. Li CM, Zhang X, Hoffman HJ, Cotch MF, Themann CL, et al. (2014). Hearing impairment associated with depression in US adults, National Health and Nutrition Examination Survey 2005-2010. JAMA otolaryngologyhead \& neck surgery 140(4): 293-302.

34. Rostami M, Bahmani B, Bakhtyari V, Movallali G (2014). Depression and deaf adolescents: a review. Iranian Rehabilitation Journal 12(1): 43-53.

35. Prakash SS, Prakash SGR, Ravichandran A, Susan KY, Alex W (2013) Measuring Levels of Stress and Depression in Mothers of Children Using Hearing Aids and Cochlear Implants: A Comparative Study. International journal of special education 28(1): 37-44.

36. Garnefski N, Kraaij V (2012) Cognitive coping and goal adjustment are associated with symptoms of depression and anxiety in people with acquired hearing loss. International journal of audiology 51(7): 545550.
37. Millán Calenti JC, Maseda A, Rochette S, García Monasterio I (2011). Relationship between sensory hearing loss and depression in elderly people: a literature review. Revista espanola de geriatria y gerontologia, 46(1): 30-35.

38. Theunissen SC, Rieffe C, Kouwenberg M, Soede W, Briaire JJ, et al. (2011) Depression in hearing-impaired children. International Journal of Pediatric Otorhinolaryngology 75(10): 1313-1317.

39. Lee AT, Tong MC, Yuen KC, Tang PS, Hasselt C (2010) Hearing impairment and depressive symptoms in an older Chinese population. Journal of Otolaryngology-Head \& Neck Surgery 39(5).

40. Spencer PE, Marschark M (2010) Evidence-based practice in educating deaf and hard-of-hearing students. Oxford University Press, USA.

41. Oyiborhoro J (2004) Aural rehabilitation for people with disabilities. BRILL.

42. Lin CS, Lin YS, Liu CF, Weng SF, Lin C, et al. (2016) Increased risk of sudden sensorineural hearing loss in patients with depressive disorders: population-based cohort study. The Journal of Laryngology \& Otology 130(1): 42-49.

43. Gomaa MAM, Elmagd MHA, Elbadry MM, Kader RM (2014) Depression, anxiety and stress scale in patients with tinnitus and hearing loss. Eur Arch Otorhinolaryngol 271: 2177-2184.

44. Sheppard K, Badger T (2010) The lived experience of depression among culturally Deaf adults. Journal of psychiatric and mental health nursing, 17(9): 783-789.

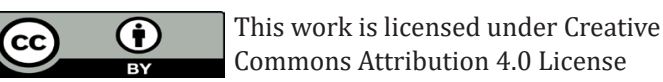

To Submit Your Article Click Here: Submit Article

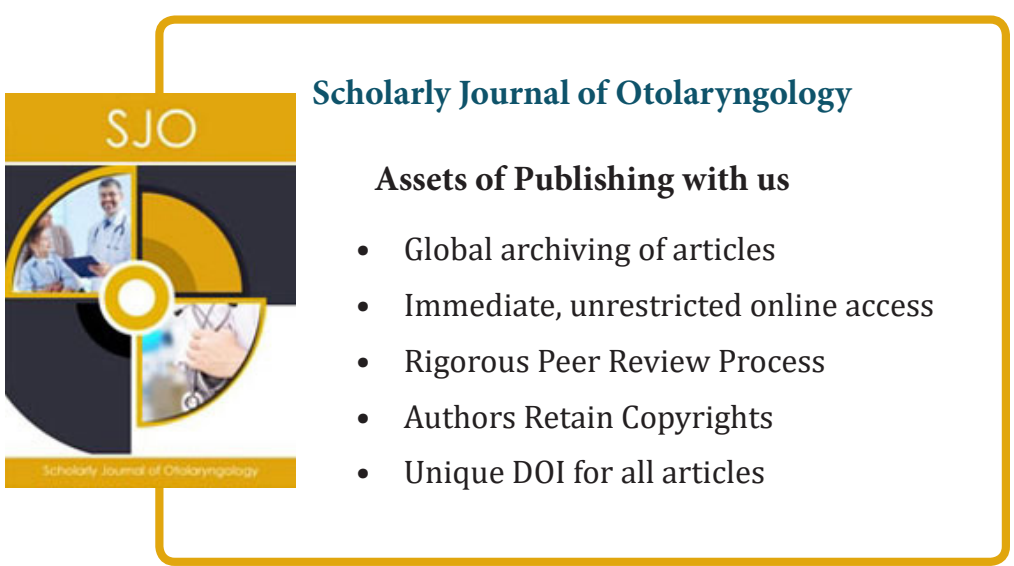

